OPEN ACCESS

Edited by:

Isabel Marques,

University of Lisbon, Portugal

Reviewed by:

Daniela Scaccabarozzi.

Curtin University, Australia

Michael John Munro Harrap, University of Bristol, United Kingdom

*Correspondence:

Casper J. van der Kooi

C.J.van.der.Kooi@rug.nl

tORCID:

Casper J. van der Koo orcid.org/0000-0003-0613-7633

Almut Kelber

orcid.org/0000-0003-3937-2808

Specialty section:

This article was submitted to Behavioral and Evolutionary Ecology,

a section of the journal

Frontiers in Ecology and Evolution

Received: 21 November 2021

Accepted: 20 January 2022

Published: 17 February 2022

Citation:

van der Kooi CJ and Kelber A (2022) Achromatic Cues Are Important for Flower Visibility

to Hawkmoths and Other Insects.

Front. Ecol. Evol. 10:819436.

doi: $10.3389 /$ fevo.2022.819436

\section{Achromatic Cues Are Important for Flower Visibility to Hawkmoths and Other Insects}

\author{
Casper J. van der Kooi ${ }^{1 * t}$ and Almut Kelber ${ }^{2 \dagger}$ \\ ${ }^{1}$ Groningen Institute for Evolutionary Life Sciences, University of Groningen, Groningen, Netherlands, ${ }^{2}$ Lund Vision Group, \\ University of Lund, Lund, Sweden
}

Studies on animal colour vision typically focus on the chromatic aspect of colour, which is related to the spectral distribution, and disregard the achromatic aspect, which is related to the intensity ("brightness") of a stimulus. Although the chromatic component of vision is often most reliable for object recognition because it is fairly context independent, the achromatic component may provide a reliable signal under specific conditions, for example at night when light intensity is low. Here we make a case for the importance of achromatic cues in plant-pollinator signalling, based on experimental data on naïve Deilephila elpenor and Macroglossum stellatarum hawkmoths, optical modelling and synthesising published experiments on bees, flies, butterflies and moths. Our experiments show that in ecologically relevant light levels hawkmoths express a strong preference for brighter stimuli. Published experiments suggest that for flowervisiting bees, butterflies, moths and flies, achromatic cues may be more important for object detection than often considered. Our optical modelling enabled disentangling the contribution of pigments and scattering structures to the flower's achromatic contrast, and illustrates how flower anatomy and background are important mediating factors. We discuss our findings in the context of the often-assumed dichotomy between detection and discrimination, chromatic versus achromatic vision, and the evolution of floral visual signals.

\footnotetext{
Keywords: brightness, hawkmoth, insect colour vision, pollination, achromatic contrast, achromatic vision, flower colour, pigment
}

\section{INTRODUCTION}

Many animals rely on colour information for numerous tasks, such as finding mates and food or avoiding predators (reviewed by Kelber et al., 2003; Cronin et al., 2014; van der Kooi et al., 2021). Colour has a chromatic aspect, which is related to the spectral distribution of the reflected or emitted light, and an achromatic aspect, which is related to the intensity or total reflectance of a stimulus (Kelber et al., 2003; Osorio and Vorobyev, 2005; Kemp et al., 2015). Hue and saturation are terms used to characterise human perception of the chromatic aspect, and brightness is used to describe the achromatic aspect of colour, though these terms are not defined for animals. In this text, we use the word "bright" to describe a colour of higher intensity and "dark" for a colour of low intensity. Likewise, we will use human colour terms to describe how colours appear to the human eye. 
Ever since the experiments on honeybee colour vision by von Frisch (1914), the use of chromatic information by animals has gained far more attention than their use of the achromatic aspect of colour. The use of the achromatic aspect of colour is seen as more "primitive" than the use of the chromatic aspect, because achromatic cues can be detected by a single spectral type of photoreceptor or a summed receptor signal (Osorio and Vorobyev, 2005), whereas chromatic vision depends on comparing signals from two or more spectral types of receptors (Kelber et al., 2003). Moreover, to demonstrate the use of colour vision in an animal, it is required to show that it uses chromatic information and to exclude the possibility that it used achromatic information (Kelber et al., 2003). This is usually done by making achromatic information unreliable in the experiment, which has led to the present situation that less is known about the use of achromatic than chromatic information in many animals.

In this essay, we call for an increased focus on the achromatic aspect of flower colour and make the case that achromatic information may be more important for flower detection and discrimination by insect pollinators than often acknowledged. The proposition is relevant for a better understanding of pollinator vision as well as flower colours. We will discuss this using five questions:

(1) Do flower-visiting insects use chromatic and achromatic signals for separate purposes as often suggested?

(2) Is there a difference between diurnal and nocturnal insects in the use of achromatic versus chromatic cues?

(3) Is there a difference in how chromatic and achromatic cues guide the innate preferences of naïve flower visitors and learned preferences for flower colours?

(4) Do chromatic and achromatic cues have different roles for the detection of flowers against the background, and for the discrimination between flowers?

(5) How do floral scattering and pigmentation properties determine the achromatic contrast?

In the following, after giving a short historical background, we will summarise basics on chromatic and achromatic vision in insects. We test the importance of achromatic contrast in an experiment with diurnal and nocturnal hawkmoths, and present evidence from literature on the importance of achromatic cues in plant-pollinator signalling. We use an optical model that enables disentangling the contribution of pigments, scattering structures and the type of background to discuss what determines the achromatic contrast between flowers and their background.

\section{HISTORICAL BACKGROUND}

Why is the use of achromatic cues often neglected? First, for many years, the goal was to understand colour vision. While already in the 17-hundreds, Sprengel (1793) noted that flowers were not colourful to appeal to humans but to attract pollinators, it took until the seminal work of Turner (1910) and von Frisch (1914) that it became broadly accepted that insects use colour information. At that time, colour vision, which is based on multiple photoreceptor types and neural comparison of their signals, was considered superior to or more derived than achromatic vision, which is possible with any spatially resolving eye.

The important notion made by von Frisch was that in order to show that an animal used colour, it needed to be clear that the animal used the chromatic aspect of colour. The achromatic aspect thus had to be negated by the experimenter (von Frisch, 1914; Kelber et al., 2003). Over the last century, colour vision has been documented in many insects, leading to the conclusion that most species use it. For example, in insects alone, the spectral sensitivities have been described in more than 200 species of 13 orders (van der Kooi et al., 2021). Behavioural studies aiming to test whether an insect species possesses colour vision need to exclude the use of achromatic information (Kelber et al., 2003; Spaethe et al., 2014; Arikawa et al., 2021), but the opposite, that is, rigorous exclusion of chromatic cues to investigate the use of achromatic cues, has very rarely been undertaken.

Second, starting with Turner's and von Frisch's work, there has long been a bias toward research on a single - albeit important - species of insect pollinators, European honeybees (Apis mellifera), because these are easy to obtain and maintain, and convenient in behavioural studies. Although research on honeybees has provided a leap in comprehension on colour vision, literature is taxonomically biased toward this species. A caveat pertaining honeybees as model system in vision research is that in honeybees there may be a comparatively strong difference between the use of chromatic and achromatic cues. Behavioural experiments suggested that honeybees (A. mellifera and $A$. cerana) use achromatic or chromatic information at different stages of their approach to flowers, depending on the subtended visual angle of a stimulus (e.g., Lehrer and Bischof, 1995; Giurfa et al., 1996, 1997; Menzel et al., 1997; Meena et al., 2021). Thus, in behavioural terms, honeybees use achromatic or chromatic contrast depending on the size of and distance to a flower. In other insects, this separation may not strictly be the case (e.g., in butterflies, Stewart et al., 2015).

Third, it was long assumed that insect chromatic and achromatic vision are processed by two different channels, with separate neural pathways (Table 1; for discussions, see Kelber and Henze, 2013). In the honeybee, behavioural experiments have shown that only the green photoreceptor (often called long-wavelength-sensitive receptor) is used for achromatic tasks such as motion and shape detection (Srinivasan, 1985; Srinivasan and Lehrer, 1988; Hempel de Ibarra and Giurfa, 2003). Achromatic vision is also used to control landing, a behaviour studied extensively in flies (e.g., Tinbergen and Abeln, 1983; Van Breugel and Dickinson, 2012) and bees (e.g., Lehrer et al., 1990). Patterns are very poorly detected by the bee's achromatic channel if they only present contrast in the UV (short-wavelength-sensitive) or blue (medium-wavelengthsensitive) photoreceptor. In flies, a similar case was posited. Six morphologically similar photoreceptors (named R1-6) with the same broadband sensitivity were assumed to feed into the motion and form vision channels, whereas the remaining two receptor types (R7/8) were assumed to feed into the colour vision channel. The fly eye is a mosaic of two ommatidial types, all with the same R1-6, but with two sub-types and different spectral 
TABLE 1 | Examples of insect pollinators and their chromatic and achromatic visual channels.

\begin{tabular}{|c|c|c|c|c|}
\hline & $\begin{array}{l}\mathrm{N} \text { spectral types of } \\
\text { receptors }\end{array}$ & Chromatic vision based on & Achromatic vision based on & Selected references \\
\hline Apidae (Hymenoptera) & UV, Blue, and Green & UV, Blue Green & Green & $\begin{array}{l}\text { Peitsch et al., 1992; Giurfa } \\
\text { et al., } 1997\end{array}$ \\
\hline Diptera & $\begin{array}{l}\text { R1-6 broadband R7/8 UV1, } \\
\text { UV2, Blue, and Green }\end{array}$ & $\begin{array}{l}\text { R7/8, plus some influence of } \\
R 1-6\end{array}$ & $\begin{array}{l}\text { R1-6, plus some influence } \\
\text { from } R 7 / 8\end{array}$ & $\begin{array}{l}\text { Wardill et al., 2012; } \\
\text { Schnaitmann et al., } 2013\end{array}$ \\
\hline Sphingidae (Lepidoptera) & UV, Blue, and Green & UV, Blue Green & $\begin{array}{l}\text { Assumed the green receptor, } \\
\text { but not confirmed }\end{array}$ & Telles et al., 2014 \\
\hline Papilio aegeus (Lepidoptera) & $\begin{array}{l}\text { Five peak sensitivities plus } \\
\text { broadband }\end{array}$ & UV, Blue, Green, and Red & Unknown & Arikawa, 2003 \\
\hline Pygopleurus israelitus (Coleoptera) & UV, Green, and Red & UV, Green, and Red & Unknown & Martínez-Harms et al., 2012 \\
\hline
\end{tabular}

$R$ indicates numbered receptor types, see references for clarification.

sensitivities in R7 (UV1 and UV2) and R8 (blue and green). Fly eyes thus have four spectrally different types of photoreceptors that are used for colour vision (Hardie, 1986). This general scheme seems to be universal among Diptera, at least for common flower visitors such as Syrphids (reviewed by van der Kooi et al., 2021).

Early work on bee and fly chromatic and achromatic colour processing led to the general assumption that achromatic and chromatic vision might be physically and behaviourally separated in insect vision in general, even though not much was known about other groups. For most insect groups, it is not clear which photoreceptor(s) is/are important for processing of achromatic information (see Table 1), but the green receptor is a suitable and likely candidate for the achromatic channel, because it is the most abundant photoreceptor type across insect eyes and thus, the green channel has the highest sensitivity (Kelber et al., 2003).

Over the last decade, however, work has revealed that the dichotomy in neural chromatic versus achromatic pathways is not universal, and that the pathways intersect in both flies and butterflies, meaning that chromatic processes feed into the achromatic channel and vice versa (Wardill et al., 2012; Kelber and Henze, 2013; Schnaitmann et al., 2013; Rusanen et al., 2018; Pagni et al., 2021). The same may apply to other insects such as moths and bees.

These three historical facets of studies on insect colour vision have contributed to our lack of understanding of the use of achromatic cues by flower visitors.

\section{WHAT MAY ACHROMATIC CUES BE USED FOR?}

The reliability of achromatic versus chromatic cues depends on biotic and abiotic conditions. Chromatic vision is often considered more reliable than achromatic vision, because it is less context dependent (Osorio and Vorobyev, 2005; Johnsen et al., 2006). Achromatic cues vary with illumination, for example caused by shadows or clouds, but also the spectral composition of the illumination, which differs between an open field and the forest, and between twilight, starlight and moonlight (Johnsen et al., 2006). By contrast, colour vision systems universally correct, at least partly, for illumination differences by means of colour constancy (reviewed by Chittka et al., 2014), so enabling the animal to recognise the same colour under varying illumination.

As compared to chromatic cues, achromatic cues represent the highest signal power and information content in any image (Osorio and Vorobyev, 2005; Vasas et al., 2017). The higher signal to noise ratio of achromatic cues has been taken as main reason why motion vision, polarisation vision as well as other visual domains that require high spatial and temporal resolution of insect vision mainly rely on achromatic input (Osorio and Vorobyev, 2005). Therefore, achromatic cues could be more important for flower detection and discrimination than often assumed.

Insect responses to achromatic cues vary markedly between species. Honeybees can detect flowers from the threefold distance using achromatic contrast, compared to chromatic contrast (Table 2). Spaethe et al. (2001) showed that in bumblebees, the relative importance of achromatic versus chromatic cues also varies with size of, or distance to, the stimulus. Smaller flowers grouped in inflorescences can be detected from further away, if they provide green receptor contrast (Wertlen et al., 2008). However, the difference between achromatic and chromatic spatial resolution is smaller in, for example, stingless bees (Dyer et al., 2016; Jezeera et al., 2021). Eristalis tenax hoverflies exhibit preferences for bright (yellow) stimuli (An et al., 2018) and Papilio xuthus butterflies prefer high achromatic contrast between flowers and their background (Kinoshita et al., 2012), but Catopsilia pomona, a diurnal pierid butterfly, did not prefer yellow flower models of higher intensity (Balamurali et al., 2020).

Even animals of the same species can give different weight to chromatic and achromatic cues, depending on context. Crepuscular flower-visitors such as the hawkmoth Manduca sexta, albeit showing a clear chromatic preference for blue flowers in twilight (Goyret et al., 2008), switch to an achromatic preference for bright flowers in dim starlight and, if flowers are seen in front of a dark background, also in moonlight levels (Kuenzinger et al., 2019). The nocturnal hawkmoth Deilephila elpenor can learn to discriminate flowers using chromatic information even in starlight, but when given the choice between different intensity versions, it exhibits preferences for darker or brighter shades of the training colour (Kelber et al., 2002). Differences in the achromatic 
TABLE 2 | Studies that enable assessing the relative importance of chromatic versus achromatic contrast in the context of flower detection and discrimination.

\begin{tabular}{|c|c|c|c|c|c|c|}
\hline Species & Stimulus & Activity & Innate/learned & $\begin{array}{l}\text { Detection - } \\
\text { discrimination }\end{array}$ & $\begin{array}{l}\text { Additional } \\
\text { findings/comments }\end{array}$ & References \\
\hline \multicolumn{7}{|l|}{ Lepidoptera } \\
\hline Macroglossum stellatarum & Paper stimuli & $\mathrm{D}$ & $\begin{array}{l}\text { Naiive animals can use } \\
\text { both chromatic and } \\
\text { achromatic contrast to } \\
\text { guide the proboscis to } \\
\text { the nectary }\end{array}$ & $\begin{array}{l}\text { Detection task: nectar } \\
\text { guide versus } \\
\text { surrounding petal } \\
\text { colour }\end{array}$ & & $\begin{array}{l}\text { Goyret and Kelber, } \\
2012\end{array}$ \\
\hline Deilephila elpenor & Paper stimuli & $\mathrm{N}$ & $\begin{array}{l}\text { Naiive animals show a } \\
\text { preference for the } \\
\text { stimulus with higher } \\
\text { intensity }\end{array}$ & Discrimination task & & Present study \\
\hline Deilephila elpenor & Paper stimuli & $\mathrm{N}$ & $\begin{array}{l}\text { After training to a } \\
\text { colour, animals use the } \\
\text { chromatic aspect to } \\
\text { choose. However, } \\
\text { when provided the } \\
\text { training colour in } \\
\text { several intensities, they } \\
\text { prefer brighter shades } \\
\text { of yellow and darker } \\
\text { shades of blue, } \\
\text { suggesting a } \\
\text { contribution of } \\
\text { achromatic vision }\end{array}$ & Discrimination task & & Kelber et al., 2002 \\
\hline Manduca sexta & Paper stimuli & C & $\begin{array}{l}\text { Naiive animals probed } \\
\text { on white lines on a } \\
\text { black or dark blue } \\
\text { flower background, but } \\
\text { avoid black or dark } \\
\text { blue lines on a white } \\
\text { background, indicating } \\
\text { that proboscis control } \\
\text { is mediated by } \\
\text { achromatic cues } \\
\text { independent of the } \\
\text { chromatic aspect }\end{array}$ & $\begin{array}{l}\text { Discrimination of nectar } \\
\text { guides, as contrast was } \\
\text { high enough for } \\
\text { detection in all cases }\end{array}$ & & Goyret, 2010 \\
\hline Helicoverpa armigera & Paper & $\mathrm{N}$ & $\begin{array}{l}\text { Animals appeared to } \\
\text { select the most } \\
\text { reflective stimuli }\end{array}$ & Discrimination task & $\begin{array}{l}\text { The setup was not } \\
\text { ideally designed for } \\
\text { testing achromatic } \\
\text { vision, as the aim was } \\
\text { different }\end{array}$ & Satoh et al., 2016 \\
\hline
\end{tabular}


TABLE 2 | (Continued)

\begin{tabular}{|c|c|c|c|c|c|c|}
\hline Species & Stimulus & Activity & Innate/learned & $\begin{array}{l}\text { Detection - } \\
\text { discrimination }\end{array}$ & $\begin{array}{l}\text { Additional } \\
\text { findings/comments }\end{array}$ & References \\
\hline Catopsilia pomona & Paper & $\mathrm{D}$ & $\begin{array}{l}\text { Naïve butterflies } \\
\text { choose equally } \\
\text { between three shades } \\
\text { of yellow differing in } \\
\text { intensity, no effect of } \\
\text { achromatic differences. } \\
\text { Learning of achromatic } \\
\text { cues was not tested }\end{array}$ & Discrimination task & $\begin{array}{l}\text { The butterflies have a } \\
\text { preference for blue over } \\
\text { all other colours, and } \\
\text { blue has low intensity }\end{array}$ & $\begin{array}{l}\text { Balamurali et al., } \\
2020\end{array}$ \\
\hline Papilio xuthus & Paper & D & $\begin{array}{l}\text { Achromatic contrast to } \\
\text { background is required } \\
\text { for the animals to land } \\
\text { on a flower }\end{array}$ & $\begin{array}{l}\text { Detection and landing } \\
\text { on flower }\end{array}$ & $\begin{array}{l}\text { The contrast seems to } \\
\text { be for the broad-band } \\
\text { receptor, alternatively } \\
\text { for a summed receptor } \\
\text { signal of UV, blue, green } \\
\text { and red receptors }\end{array}$ & $\begin{array}{l}\text { Koshitaka et al., } \\
2011\end{array}$ \\
\hline Papilio xuthus & $\begin{array}{l}\text { Paper, neutral } \\
\text { density filters }\end{array}$ & $\mathrm{D}$ & $\begin{array}{l}\text { Naive animals prefer } \\
\text { the brighter of two } \\
\text { stimuli. They can learn } \\
\text { to choose the brighter } \\
\text { or darker of two stimuli, } \\
\text { but learning is slower } \\
\text { than for chromatic cues }\end{array}$ & Discrimination task & $\begin{array}{l}\text { Tested with } \\
\text { backgrounds of } \\
\text { different intensities, the } \\
\text { animals can use } \\
\text { simultaneous } \\
\text { brightness contrast, } \\
\text { something rarely tested } \\
\text { in insects }\end{array}$ & $\begin{array}{l}\text { Kinoshita et al., } \\
2012\end{array}$ \\
\hline \multicolumn{7}{|l|}{ Diptera } \\
\hline Eristalis tenax & Paper & $\mathrm{D}$ & $\begin{array}{l}\text { Trained animals } \\
\text { preferred stimuli of } \\
\text { higher intensity, } \\
\text { particularly with yellow } \\
\text { hues, independent of } \\
\text { the brightness of the } \\
\text { learned colour }\end{array}$ & Discrimination task & $\begin{array}{l}\text { The main focus of the } \\
\text { study was on chromatic } \\
\text { vision }\end{array}$ & An et al., 2018 \\
\hline Apis mellifera & $\begin{array}{l}\text { Mono-chromatic } \\
\text { and white light }\end{array}$ & D & Learned behaviour & Discrimination & $\begin{array}{l}\text { In dim light, bees } \\
\text { choose the stimulus of } \\
\text { higher intensity, even } \\
\text { after training to the } \\
\text { other stimulus }\end{array}$ & Menzel, 1981 \\
\hline Apis mellifera & Paper stimuli & $\mathrm{D}$ & Trained behaviour & $\begin{array}{l}\text { Edge detection and } \\
\text { landing }\end{array}$ & $\begin{array}{l}\text { Edge detection and } \\
\text { landing is colour-blind } \\
\text { and requires contrast in } \\
\text { the green receptor }\end{array}$ & Lehrer et al., 1990 \\
\hline Apis mellifera & Paper stimuli & D & Learned behaviour & $\begin{array}{l}\text { Detection: For flower } \\
\text { cues without chromatic } \\
\text { contrast to } \\
\text { background, detection } \\
\text { threshold ( } 3^{\circ} \text { angular } \\
\text { size) depends on } \\
\text { achromatic (green } \\
\text { receptor) contrast }\end{array}$ & & $\begin{array}{l}\text { Lehrer and Bischof, } \\
1995\end{array}$ \\
\hline
\end{tabular}


TABLE 2 | (Continued)

\begin{tabular}{|c|c|c|c|c|c|c|}
\hline Species & Stimulus & Activity & Innate/learned & $\begin{array}{l}\text { Detection - } \\
\text { discrimination }\end{array}$ & $\begin{array}{l}\text { Additional } \\
\text { findings/comments }\end{array}$ & References \\
\hline Apis mellifera & Paper stimuli & $D$ & Learned behaviour & Detection & $\begin{array}{l}\text { Bees learn achromatic } \\
\text { (green receptor) cues at } \\
\text { small visual angles }\left(5^{\circ}\right) \text {, } \\
\text { though this is harder for } \\
\text { them than learning } \\
\text { chromatic cues }\end{array}$ & $\begin{array}{l}\text { Giurfa et al., 1996, } \\
\text { 1997; Giurfa and } \\
\text { Vorobyev, } 1998\end{array}$ \\
\hline Apis mellifera & Paper stimuli & $\mathrm{D}$ & Learned behaviour & $\begin{array}{l}\text { Both chromatic and } \\
\text { achromatic (green } \\
\text { receptor) contrast } \\
\text { mediate detection of } \\
\text { coloured patterns }\end{array}$ & $\begin{array}{l}\text { For large targets } \\
\left(\geq 15^{\circ}\right) \text {, chromatic } \\
\text { contrast is most } \\
\text { important }\end{array}$ & $\begin{array}{l}\text { Hempel de Ibarra } \\
\text { et al., 2000, 2001; } \\
\text { Niggebrügge and } \\
\text { Hempel de lbarra, } \\
2003\end{array}$ \\
\hline Apis mellifera & Paper stimuli & $\mathrm{D}$ & Learned behaviour & Discrimination & $\begin{array}{l}\text { Only achromatic (green } \\
\text { receptor) contrast is } \\
\text { used for shape } \\
\text { discrimination }\end{array}$ & $\begin{array}{l}\text { Hempel de Ibarra } \\
\text { and Giurfa, } 2003\end{array}$ \\
\hline Apis mellifera & Paper stimuli & D & Learned behaviour & Detection & $\begin{array}{l}\text { With achromatic (green } \\
\text { receptor) contrast } \\
\text { present, grouping of } \\
\text { small stimuli improves } \\
\text { detection }\end{array}$ & Wertlen et al., 2008 \\
\hline Apis mellifera & Paper stimuli & $D$ & Learned behaviour & $\begin{array}{l}\text { Detection (Experiment } \\
\text { 1) and discrimination } \\
\text { (Experiment 2) both use } \\
\text { achromatic information }\end{array}$ & $\begin{array}{l}\text { Only green receptor } \\
\text { contrast explained the } \\
\text { detection of orange } \\
\text { from dark grey. Both } \\
\text { green receptor contrast } \\
\text { and chromatic contrast } \\
\text { together explained } \\
\text { discrimination from } \\
\text { other flower colours }\end{array}$ & $\begin{array}{l}\text { Reisenman and } \\
\text { Giurfa, } 2008\end{array}$ \\
\hline Apis mellifera & Paper stimuli & $\mathrm{D}$ & Learned behaviour & $\begin{array}{l}\text { Detection: the animals } \\
\text { could not detect } \\
\text { flowers of } 28^{\circ} \\
\text { extension, if they } \\
\text { presented no chromatic } \\
\text { contrast to the grey } \\
\text { background }\end{array}$ & $\begin{array}{l}\text { Green receptor contrast } \\
\text { and summed receptor } \\
\text { contrast are not learned } \\
\text { in this situation }\end{array}$ & Ng et al., 2018 \\
\hline Apis cerana & Paper stimuli & $\mathrm{D}$ & Learned behaviour & $\begin{array}{l}\text { Detection threshold for } \\
\text { flowers with achromatic } \\
\text { and chromatic contrast } \\
\text { is } 7.7^{\circ} \text {, for flowers with } \\
\text { only chromatic contrast } \\
13.2^{\circ}\end{array}$ & & Meena et al., 2021 \\
\hline Bombus terrestris & $\begin{array}{l}\text { Artificial flowers of } \\
\text { different sizes }\end{array}$ & $\mathrm{D}$ & Learned behaviour & Detection & $\begin{array}{l}\text { When searching for } \\
\text { large targets chromatic } \\
\text { contrasts are used. For } \\
\text { small targets, } \\
\text { achromatic (green } \\
\text { receptor) contrast is } \\
\text { used }\end{array}$ & $\begin{array}{l}\text { Spaethe et al., } \\
2001\end{array}$ \\
\hline Bombus terrestris & Paper stimuli & $D$ & Learned behaviour & Detection & $\begin{array}{l}\text { With green receptor } \\
\text { contrast present, } \\
\text { grouping of small } \\
\text { stimuli improves } \\
\text { detection }\end{array}$ & Wertlen et al., 2008 \\
\hline Melipona mondury & Powder mixes & $\mathrm{D}$ & $\begin{array}{l}\text { Preference in several } \\
\text { colour combinations in } \\
\text { series, visits to all } \\
\text { stimuli were rewarded }\end{array}$ & $\begin{array}{l}\text { Discrimination of two } \\
\text { colours, no consistent } \\
\text { effect of achromatic } \\
\text { cues }\end{array}$ & $\begin{array}{l}\text { Background colour } \\
\text { (green or grey) had an } \\
\text { effect }\end{array}$ & Koethe et al., 2016 \\
\hline
\end{tabular}


TABLE 2 | (Continued)

\begin{tabular}{|c|c|c|c|c|c|c|}
\hline Species & Stimulus & Activity & Innate/learned & $\begin{array}{l}\text { Detection - } \\
\text { discrimination }\end{array}$ & $\begin{array}{l}\text { Additional } \\
\text { findings/comments }\end{array}$ & References \\
\hline Melipona quadrifasciata & Powder mixes & $\mathrm{D}$ & $\begin{array}{l}\text { Preference in several } \\
\text { colour combinations in } \\
\text { series, visits to all } \\
\text { stimuli were rewarded }\end{array}$ & $\begin{array}{l}\text { Discrimination of two } \\
\text { colours, no consistent } \\
\text { effect of achromatic } \\
\text { cues }\end{array}$ & & Koethe et al., 2016 \\
\hline Tetragonula carbonaria & Paper stimuli & $\mathrm{D}$ & Learned behaviour & $\begin{array}{l}\text { Detection threshold is } \\
\text { similar (visual angle) for } \\
\text { stimuli with and without } \\
\text { achromatic (green } \\
\text { receptor) contrast }\end{array}$ & & Dyer et al., 2016 \\
\hline Tetragonula iridipennis & Paper stimuli & $\mathrm{D}$ & Learned behaviour & $\begin{array}{l}\text { Detection threshold for } \\
\text { target with both } \\
\text { chromatic and } \\
\text { achromatic contrast is } \\
9^{\circ} \text {, with only chromatic } \\
\text { contrast } 11.5^{\circ}\end{array}$ & & Jezeera et al., 2021 \\
\hline Tetralonia lerlandi & $\begin{array}{l}\text { Paper perianth, real } \\
\text { flower }\end{array}$ & & $\begin{array}{l}\text { At distances }<30 \mathrm{~cm} \text {, } \\
\text { the male search time } \\
\text { for Ophrys dummy } \\
\text { flowers with different } \\
\text { perianth colours was } \\
\text { correlated with } \\
\text { achromatic, but not } \\
\text { chromatic contrast to } \\
\text { the green background }\end{array}$ & Detection task & $\begin{array}{l}\text { At distances }>30 \mathrm{~cm} \text {, } \\
\text { search time was } \\
\text { affected by wind speed } \\
\text { (olfaction), but not by } \\
\text { the visual properties of } \\
\text { the perianth }\end{array}$ & $\begin{array}{l}\text { Streinzer et al., } \\
2009\end{array}$ \\
\hline
\end{tabular}

D, diurnal; N, nocturnal; C, crepuscular.

cues of flowers may result in changes in plant reproductive success; for example, nutrient deficiency can lead to lower amounts of floral pigment, which reduces flower chromatic and achromatic contrast (Ausma et al., 2021), and shaded flowers may suffer from reduced visitation by insect pollinators (Ushimaru et al., 2021). Generally, the relative importance of chromatic versus achromatic signals in detection and discrimination of flowers by insect pollinators remains largely unknown, partly because studies on insect vision are greatly biassed toward the chromatic aspect (Kelber and Osorio, 2010; Hempel de Ibarra et al., 2014).

In the following, we take a three-way approach to evaluate the importance of achromatic information for flower detection by flower-visiting insects. We present results from a behavioural experiment on responses of flower-naïve diurnal and nocturnal hawkmoths to stimuli that differ solely in intensity. Thereafter we discuss what is known from literature on the use of chromatic cues by flower-visiting insects. Finally, we use an optical model to better understand the contribution of pigment, scattering structures and type of background for the achromatic contrast between flowers and their background.

\section{BEHAVIOURAL EXPERIMENTS WITH DIURNAL AND NOCTURNAL HAWKMOTHS}

Pupae of the nocturnal D. elpenor and the diurnal Macroglossum stellatarum, bred on the natural larval food plant (Galium sp.), were placed in a flight cage at room temperature in a 12:12 h light:dark cycle for eclosure. Tests were performed in a separate flight cage $(65 \mathrm{~cm} \times 65 \mathrm{~cm} \times 80 \mathrm{~cm}$ height $\times$ depth $\times$ width $)$ with three walls from light grey cloth and one long wall from transparent plastic for observation. The cage, placed in an otherwise dark room, was diffusely illuminated from above with an array of LEDs (Goobay LED strip flex 33 SMD white, max 132 lumen) pointing upward toward an aluminium reflector (Figure 1A). The intensity was adjusted to 10 lux for D. elpenor ( $\approx$ nautical twilight) and to 100 lux ( $\approx$ civil twilight) for M. stellatarum, as measured in the centre of the cage (using Hagner Screen Master, Hagner AB Solna Sweden). The two illumination intensities were chosen as similar as possible but also to account for the fact that $D$. elpenor is nocturnal, while M. stellatarum is diurnal, but extends its flight into the evening twilight (Herrera, 1992).

The flat visual display, printed on paper, $20 \mathrm{~cm}$ high and $28 \mathrm{~cm}$ wide, with a green background (spectrum in Figure $2 \mathbf{B}$ ) and two circular blue flower-like stimuli of $2 \mathrm{~cm}$ diameter, in the centre, but $7 \mathrm{~cm}$ apart, was presented vertically on a stand about $5 \mathrm{~cm}$ in front of the cage wall opposite the wall covered with transparent plastic (for a figure of a similar set-up please see Telles et al., 2014). As the preference of naïve moths was to be tested, we did not provide any reward to the moths. The stimuli, hereafter called Light Blue and Dark Blue, had the same chromatic properties but different intensities (achromatic properties) (Figure 1B). The illumination spectrum (Figure 1A) was measured using a calibrated spectroradiometer (RSP900-R; International Light, Peabody, MA, United States). Reflectance spectra of stimuli and background (Figure 1B) were measured using an integrating sphere and the same setup, following standard routines 

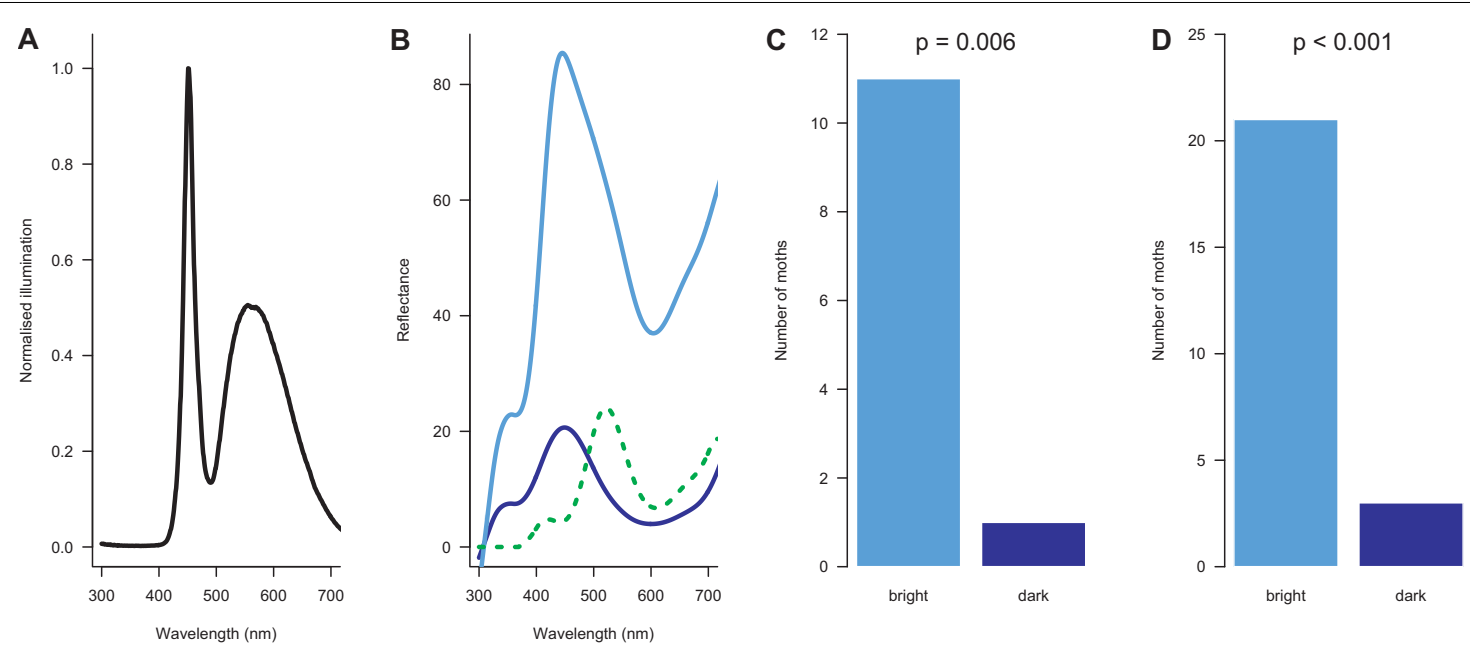

FIGURE 1 | Preference of hawkmoths for brighter stimuli. (A) Spectrum of the cage illumination. (B) Reflectance spectra of Dark Blue (dark blue curve) and Light Blue (light blue curve) stimuli and background (dashed green curve). (C) Deilephila elpenor first choices. (D) Macroglossum stellatarum first choices.

(van der Kooi et al., 2016, 2017). The used reference was a diffuse, white tile (Avantes WS-2).

Each newly eclosed, flower-naïve moth was tested once and individually, on the day of eclosion, in their respective activity period (first $2 \mathrm{~h}$ of night, for $D$. elpenor, daytime for M. stellatarum). A new stimulus array was used for each moth, and the position of Light Blue and Dark Blue (right or left side) was randomised. Hawkmoths do not land on flowers, but approach and probe them with the extended proboscis. Therefore, a single moth was released into the cage and given time to warm up, and the first time it approached and probed one of the stimuli with the extended proboscis was counted as choice. Only the first choice was registered to avoid pseudoreplication. Moths that did not approach and probe the stimulus display within $5 \mathrm{~min}$ after taking flight (three D. elpenor and four M. stellatarum), were considered not motivated to feed and removed. None of the moths probed the green background.

Twelve moths of D. elpenor approached the stimulus display with the extended proboscis and probed at least one stimulus. Of these moths, eleven approached Light Blue first, whereas one chose Dark Blue ( $p=0.006$, exact binomial test; $99 \%$ confidence interval: $0.52-1.00)$. Of $24 \mathrm{M}$. stellatarum, 21 probed Light Blue ( $\mathrm{p}<0.01$, exact binomial test, confidence interval: 0.61-0.99). In both species, this indicates a significant preference for the stimulus with higher reflectance and intensity (Figures 1C,D). A similar preference for the brighter of the two shades of the same colour has earlier been shown for M. stellatarum (Kelber, 2005); that study had been performed under higher illumination intensity ( $\approx 4,000 \mathrm{lux}$ ) and used (monochromatic) light sources with fairly high intensity differences as stimuli, whereas the stimuli used here are more similar to natural flowers. Although the peak reflectance of the Light Blue stimulus used here is still somewhat higher (80\%) than the highest reflectance found in flowers ( $60 \%$; van der Kooi et al., 2016, 2017), the strong preference (Figures 1C,D) can likely be generalised to natural flowers.

\section{WHAT DOES PUBLISHED LITERATURE SUGGEST ABOUT THE USE OF ACHROMATIC CUES BY INSECTS?}

We synthesised the findings of 32 experimental studies that investigated the importance of achromatic versus chromatic aspects of colour in object detection/recognition for in total 15 insect species of bees, butterflies, moths and flies (Table 2). We did not list studies that solely investigated chromatic vision, without allowing any insight into the use or lack of use of achromatic cues, and also exclude literature dealing with the use of achromatic or single receptor cues for motion vision or polarisation vision. We also excluded most literature on landing responses, the use of polarised light stimuli and other behaviours that are not directly involved in flower detection or discrimination. We focussed on the use of achromatic cues in the direct context of flower detection and flower discrimination, separating between preferences of flower-naïve (or generally untrained) individuals and individuals that had learned to retrieve a reward from a specific type of flower. As many publications focus on chromatic aspects and mention reactions to achromatic contrast in passing, our list is likely not complete, but it clearly indicates the many ways in which achromatic information is used by different species of pollinators. We posed five questions, and summarise below what we have learned with respect to each of them, also giving some details in Table 2.

\section{Do Flower-Visiting Insects Use Chromatic and Achromatic Signals for Separate Purposes as Often Suggested?}

It is commonly assumed that insects use chromatic and achromatic cues for different purposes (see "Historical Background"). Specifically for bees, it has been suggested that chromatic cues are important for flower detection and recognition, whereas achromatic channels guide motion vision 
and other behaviours. However, this separation may be less complete than previously assumed. Although chromatic cues are learned faster and used more frequently than achromatic cues, achromatic cues can be learned in the context of object - and flower - detection and recognition (Table 2). Several species of moths, flies and bees exhibited an innate preference for high intensity stimuli and/or chose stimuli more (rapidly) in the presence of achromatic cues (Table 2). Only in three species of stingless bees and one tested butterfly species, no effect of achromaticity was found (Table 2).

On the other hand, $P$. xuthus butterflies use both chromatic and achromatic cues for the control of landing (see Table 2), a task which is controlled exclusively by achromatic cues in bees and flies. Whereas landing is an important behaviour for pollination, the literature on landing responses was not included in Table 2, because there is general agreement that insects use achromatic vision for this behaviour (see "Historical Background"). Macroglossum stellatarum moths use both achromatic and chromatic cues for finding the entrance to the nectar reservoir (Goyret and Kelber, 2012). Thus, as to be expected from the anatomical and physiological findings that achromatic and chromatic channels are not entirely separated (see "Historical Background"), they both can, at least to some degree, influence the same behaviours to a larger degree than was earlier appreciated.

\section{Is There a Difference Between Diurnal and Nocturnal Insects in the Use of Achromatic Versus Chromatic Cues?}

Colour vision and the use of chromatic versus achromatic cues have been studied in fewer nocturnal than diurnal insects. A direct comparison can only be made between the diurnal hawkmoth M. stellatarum and the nocturnal species D. elpenor (see Figure 1). Although many nocturnal insects, including $D$. elpenor and the nocturnal carpenter bee Xylocopa tranquebarica (Somanathan et al., 2008), have (exquisite) colour vision, given the adaptations to increase light capture found in the eyes of nocturnal insects (reviewed by Nilsson, 2021), it is tempting to hypothesise that stimulus intensity plays a role in visibility to many nocturnal insects.

Our behavioural experiments showed that when given the choice between two flowers, naïve individuals express a clear preference for a more reflective, brighter stimulus (Figure 1). The crepuscular hawkmoth Manduca sexta was tested with conflicting cues and revealed that under bright light conditions, and with a bright background, they preferred dark blue to white (without UV) flowers, but this changed both with light and background, and in dimmest light levels and with dark backgrounds, the preference clearly shifted to white (Table 2; Kuenzinger et al., 2019).

It has been reported that in honeybees "colour vision disappears" in dim light (Menzel, 1981), but this happens in light intensities when they do not normally fly and forage. Only one nocturnal bee species, the carpenter bee $X$. tranquebarica, has ever been tested for colour vision at night, and this was not done in the context of flower visits, but at the nest entrance. If we assume that their use of cues is similar in both situations, we could conclude that chromatic information remains more important for that species than achromatic information. Bees trained to associate their nest entrance with a yellow marker, consistently searched at yellow markers, independent of intensity cues, and disregarded markers of other colours even if they matched the intensity of the learned marker (Somanathan et al., 2008).

Based on the limited number of species tested it seems that the use of achromatic information indeed differs between situations and light conditions, but whether there are overall differences between diurnal and nocturnal species remains unclear.

\section{Is There a Difference in How Chromatic and Achromatic Cues Guide the Innate and Learned Preferences of Flower Visitors?}

Innate colour preferences are considered to shape foraging behaviour in various insect groups. Both bees and moths have been shown to be able to learn colours other than what they innately prefer (van der Kooi et al., 2019), whereas syrphid flies seem to more strongly adhere to their innate preferences (Lunau and Maier, 1995; An et al., 2018). For the spontaneous preferences of flower-naïve animals, we see clear evidence for the use of achromatic cues in moths (Satoh et al., 2016; Kuenzinger et al., 2019; this study), but not in bees, flies or butterflies (Table 2). Bees, butterflies and moths can learn achromatic cues, but when given a conflicting situation, they will rely more heavily on the chromatic aspect. A tendency to rely on chromatic aspects in conflicting situations is likely directly related to the fact that chromatic information is more stable under changing light conditions. Colour constancy, demonstrated in these groups (Werner et al., 1988; Balkenius and Kelber, 2004) will allow an animal to commonly distinguish a yellow flower from a green background, independent of changes in illumination colour, which can be quite dramatic between shade and sun, and between late twilight an a moonlit night (Johnsen et al., 2006).

\section{Do Chromatic and Achromatic Cues Have Different Roles for the Detection of Flowers Against the Background, and for the Discrimination Between Flowers?}

Pollinators have two discrimination tasks to solve: first, they need to discriminate a flower from its background, and also from other flowers, which may not be rewarding. That first task is often referred to as detection. In addition to colour cues, insects can rely on depth cues to discriminate between objects and their background, often using motion parallax, which relies on achromatic contrast between flower and background (see "Historical Background," e.g., Lehrer et al., 1990). We have not included other references to this in Table 2, as little has been done on flower-visiting insects. However, butterflies require achromatic contrast to land on flowers (Koshitaka et al., 2011), and M. stellatarum needs achromatic contours to stabilise 
hovering flight in front of a flowers (reviewed by Stöckl and Kelber, 2019).

The detection from the background is a more complex problem, as flowers can be seen in front of many different backgrounds, such as a clear blue featureless sky, a sky with moving clouds, dark green vegetation which can also be moving, and soil or human-made structures of various colours. Most of these backgrounds are different in colour from flowers. Although natural background structures (i.e., leaves, soil, and rocks) are roughly similarly achromatic (Menzel and Shmida, 1993; Ellis et al., 2021), recent studies showed that variation in background colour can determine the salience of flowers to pollinators. Bukovac et al. (2017) modelled flower salience against more than 500 natural backgrounds and found that background colour has the potential to significantly change a flower's colour contrast. A recent study by Finnell and Koski (2021) showed that bee and fly colour preferences for ultraviolet flower markings depends on the type of background, though this preference difference depended on chromatic and not achromatic properties. The findings from Menzel et al. (1997) that desert plants exhibit lower achromatic contrast than plants in the Mediterranean due to differences in background and not flower colour also suggests that achromatic aspects of backgrounds are important. However, the discrimination between neighbouring flowers presented against one background may be more challenging when these flowers have similar colours. The smaller the chromatic or achromatic difference is, the higher sensitivity is needed.

Studies on European honeybees have found that these flowervisitors can both detect (and discriminate) flowers that exhibit achromatic contrast from a three times larger distance (with a subtended visual angle of $5^{\circ}$ ) than flowers presenting chromatic contrast $\left(15^{\circ}\right)$, and a similar result is found for the Asian honeybee (see Table 2 for references). A smaller difference has been observed in bumblebees (Dyer et al., 2008; Wertlen et al., 2008) and stingless bees (Dyer et al., 2016; Jezeera et al., 2021). Honeybees use achromatic and chromatic contrast in similar ways for detection of flowers from the background, for discrimination between differently coloured flowers and for discrimination of flower patterns (Hempel de Ibarra et al., 2000, 2001; Niggebrügge and Hempel de Ibarra, 2003). We therefore conclude that achromatic and chromatic information is used for both flower detection and discrimination. Nevertheless, because the achromatic channel often has a higher spatial resolution (see above) it might be more important in the detection task.

\section{How Do Floral Scattering and Pigmentation Properties Determine the Achromatic Contrast?}

Flowers differ from their background in both the chromatic and achromatic aspect of colour (Chittka et al., 1994; Kevan et al., 1996; Menzel et al., 1997; van der Kooi et al., 2019). It is generally assumed that achromatic contrast is determined by the type of pigment (Kevan et al., 1996; Narbona et al., 2021). For example, white and yellow flowers generally exhibit higher achromatic contrast than blue, purple and red flowers. However, flower colour is not only determined by pigments, but also by structures that scatter incident light, such as cell walls, starch granules and the flower's surface (van der Kooi et al., 2016; Stavenga et al., 2020). Flowers generally consist of different layers, such as the epidermis, mesophyll and starch layer, which all scatter part of the incident light. The reflectance of a flower increases when individual layers become more inhomogeneous or when the number of layers increases. How the scattering properties of flowers determine the achromatic contrast is largely unstudied.

To gain a more quantitative understanding of how achromatic contrast varies for different types of pigmentation and the amount of scattering, we deployed our previously devised optical model (Stavenga and van der Kooi, 2016). The optical model is based on the Kubelka-Munk theory for scattering and absorbing media and relies on spectral measurements as input. The model enables to systematically investigate the contribution of different optical properties, such as the amount of scattering or pigmentation (van der Kooi et al., 2016, 2017; van der Kooi and Stavenga, 2019). We used a white, blue, yellow and ultraviolet-reflecting red flower (Silene latifolia-alba, Nolana paradoxa, Oenothera macrocarpa, and Papaver rhoeas, respectively), systematically varied their scattering coefficient independent from pigmentation properties and calculated the achromatic contrast against a green leaf or blue-sky background (D65, midday). Achromatic contrast was calculated as the von Kries-corrected difference in excitation of the honeybee's longwavelength (green) photoreceptor between the stimulus and background (Supplementary Figure 1), after Spaethe et al. (2001). For details on the modelling and parameter setting, see methods in van der Kooi (2021).

Modelling achromatic contrast as a function of the amount of light scattering revealed clear differences between the type of pigment and backgrounds, though for all modelled cases the response curves are very similar in shape. There is a pattern of diminishing returns for all colours and backgrounds: the strongest changes in achromatic contrast are obtained when the scattering coefficient is low (Figure 2). At very high scattering coefficients $(>10)$, the achromatic contrast curve plateaus for all colours and backgrounds. The scattering coefficients found in flowers in nature varies between $\sim 1$ and 10 (van der Kooi et al., 2016, 2017), presumably due to mechanical constraints associated with flower thickness and interior inhomogeneity, which are the principal factors that determine backscattering. From the modelling (Figure 2) it becomes clear that producing flowers with extremely high backscattering also provides little benefit in terms of achromatic contrast and visibility.

Against a green leaf background, white and yellow flowers exhibit higher achromatic contrast than blue and red flowers (Figures 2A,C). The achromatic contrast of yellow and white flowers is also comparatively high regardless of the amount of scattering, because their pigments absorb light over a small wavelength range. Achromatic contrast further increases with scattering but plateaus around 0.4 , close to the maximum contrast that is theoretically possible $(0.5)$. The modelled blue and red flowers exhibit low achromatic contrast (Figures 2B,D), although this also increases with scattering coefficient. Against a blue sky the opposite occurs: 

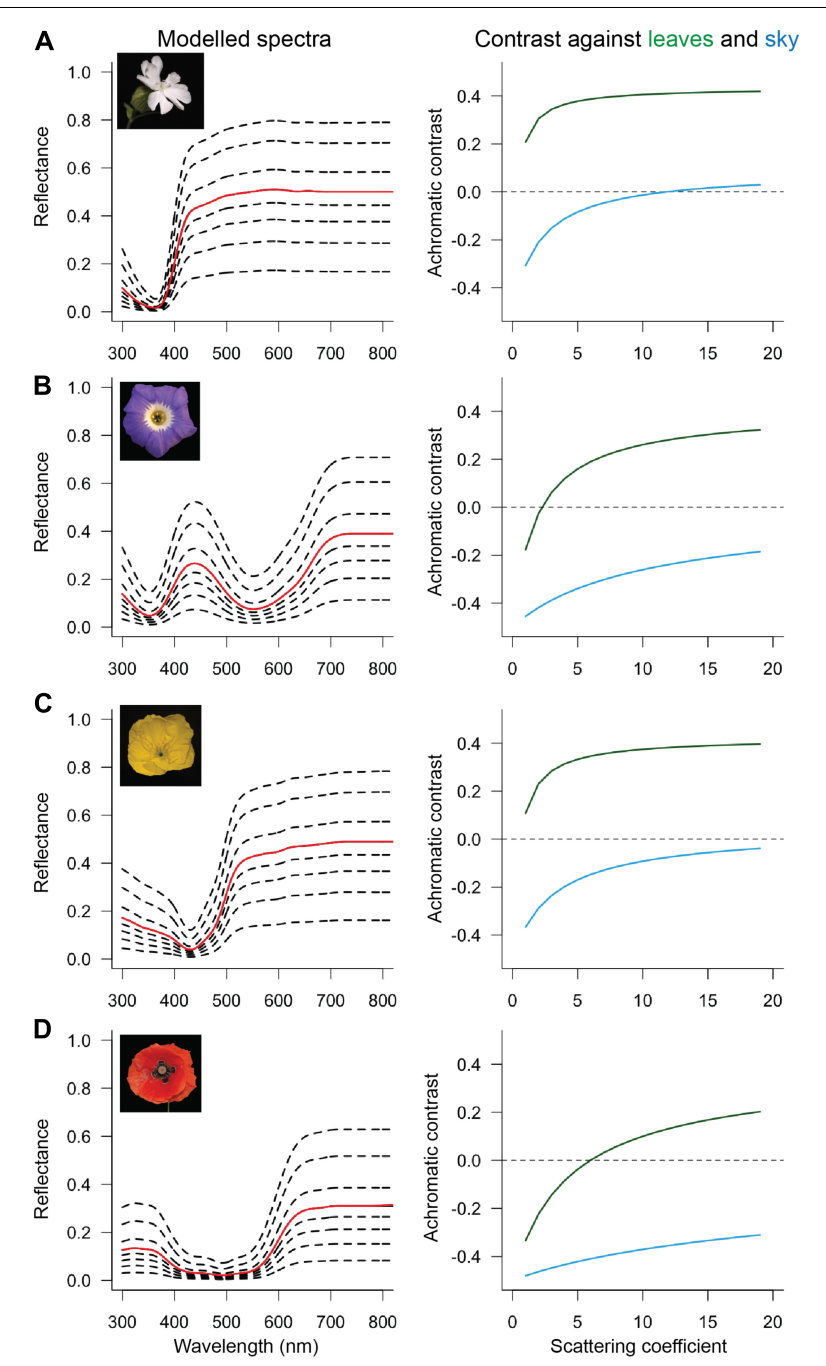

FIGURE 2 | Modelling achromatic contrast for different flower colours and scattering. The left column shows the measured reflectance spectra (red curve) and several modelled cases with higher and lower scattering coefficients (dashed curves). The right column shows the achromatic contrast of different modelled spectra against a green leaf background (green curves) and against a blue sky (blue curves). The measured reflectance is identical to the fifth modelled spectrum, so at scattering coefficient $=5$. Although achromatic contrast is normally expressed in absolute values because its direction (positive or negative) is irrelevant, for visualisation purposes we did not normalise contrast values, so contrast is relative to 0 . (A) Silene latifolia, (B) Nolana paradoxa, (C) Oenothera macrocarpa, and (D) Papaver rhoeas. For the background spectra please see Supplementary Figure 1.

blue and red flowers exhibit a much higher achromatic contrast than white and yellow flowers, at least with low scattering coefficients, because these colours are comparatively dark against the bright sky. Nevertheless, when flowers are high up a tree or stalk and presented against the sky background, the visual signal for pollinators may also be determined by the transmission instead of the reflection, or a combination of both, which may differ in spectral composition and intensity (van der Kooi et al., 2016).
Our modelling illustrates how flower colour and structure, as well as the type of background determines a flower's achromatic contrast. Overall, the relationship between achromatic contrast and scattering coefficient mimics the response of colour contrast as a function of the amount of pigment (van der Kooi, 2021). For weakly pigmented flowers, an increase in the amount of pigmentation yields a stronger increase in visibility than in flowers that have a moderate amount of pigment (van der Kooi, 2021). Future studies could reveal whether there are trade-offs in visibility via the chromatic versus the achromatic channel, how that translates to different flower pigmentation and anatomy, as well as whether the flower's location on the plant and the type of background are driving factors for the evolution of the optical properties of flowers.

\section{CONCLUDING REMARKS}

Research on animal vision traditionally focussed more on the chromatic aspect than the achromatic aspect. Various factors contributed to this bias, e.g., the presumed dichotomy in signal processing between the achromatic and chromatic channel as well as the taxonomic bias toward honeybees as model system. In a changing light environment, chromatic information is more invariant and robust than achromatic information. On the other hand, achromatic cues have a higher signal to noise ratio, particularly in dim light. Presumably therefore, during daytime or in constantly changing illumination conditions, chromatic vision may be more reliable, whereas in dim light, achromatic vision may be more useful than chromatic vision. Our behavioural experiment suggests that naive $M$. stellatarum and $D$. elpenor hawkmoths prefer a higher intensity to a lower intensity stimulus if both stimuli have the same chromatic properties. Various studies tested the detection and discrimination of stimuli with and without achromatic contrast to the background (Table 2). The overall picture is that, overall, chromatic contrast largely determines a stimulus' detectability, particularly at short distances; however, achromatic contrast contributes to visibility both physiologically as well as behaviourally. Achromatic information feeds into the colour vision channel (see "Historical Perspective") and it mediates detection of stimuli by bees, flies, butterflies, and moths (Table 2). For several species-groups, however, it is still unknown which type of photoreceptor is most important for achromatic signal detection (Table 1). Presumably, the use of achromatic cues also plays a role in detecting oviposition sites for herbivorous insects (Prokopy et al., 1975; Blake et al., 2020; Yang et al., 2020).

The finding that achromatic cues are important for flower detection by bees, flies, butterflies and moths has broader relevance for flower colour evolution. Chromatic cues may be most important for diurnal flowers pollinated by bees, butterflies or birds, and achromatic cues may be particularly important for flowers that are pollinated at night. In addition to diurnal and nocturnal hawkmoths that show a preference for stimuli of high intensity (this study), bats use colour-blind rod vision at night (Borges et al., 2016) and thus rely on achromatic visual signals. It has frequently been noted that nocturnal 
pollinated flowers are often white or yellow (e.g., Kevan and Baker, 1983), which both appear bright to animals that use the long-wavelength photoreceptor for achromatic vision. Our optical modelling showed that scattering properties crucially determine the achromatic contrast of flowers (section "How Do Floral Scattering and Pigmentation Properties Determine the Achromatic Contrast?"). We therefore propose that not just the pigments, but also the amount of reflected light determines the visibility and brightness of nocturnal pollinated flowers. This means that flowers pollinated at night may evolve structural features that enhance reflectance, e.g., more cell layers or more strongly scattering structures. Further, selective pressures on floral visual signals may be coupled with floral display size. Larger displays will be noticeable from longer distances and this process is mediated particularly by achromatic vision. Small flowers may thus compensate for their limited visibility via extra reflectance and achromatic contrast. We welcome future experimental studies on pollinator vision and comparative studies on the optical properties of the flowers that they pollinate.

\section{DATA AVAILABILITY STATEMENT}

The original contributions presented in the study are included in the article/Supplementary Material, further inquiries can be directed to the corresponding author.

\section{REFERENCES}

An, L., Neimann, A., Eberling, E., Algora, H., Brings, S., and Lunau, K. (2018). The yellow specialist: dronefly Eristalis tenax prefers different yellow colours for landing and proboscis extension. J. Exp. Biol. 221:jeb184788. doi: 10.1242/ jeb. 184788

Arikawa, K. (2003). Spectral organization of the eye of a butterfly, Papilio. J. Comp. Physiol. A 189, 791-800. doi: 10.1007/s00359-003-0454-7

Arikawa, K., Nakatani, Y., Koshitaka, H., and Kinoshita, M. (2021). Foraging small white butterflies, Pieris rapae, search flowers using color vision. Front. Ecol. Evol. 9:178.

Ausma, T., Bansal, V., Kraaij, M., Verloop, A. C. M., Gasperl, A., Müller, M., et al. (2021). Floral displays suffer from sulphur deprivation. Environ. Exp. Bot. 192:104656. doi: 10.1016/j.envexpbot.2021.104656

Balamurali, G. S., Rose, S., Somanathan, H., and Kodandaramaiah, U. (2020). Complex multi-modal sensory integration and context specificity in colour preferences of a pierid butterfly. J. Exp. Biol. 223:jeb223271. doi: 10.1242/jeb. 223271

Balkenius, A., and Kelber, A. (2004). Colour constancy in diurnal and nocturnal hawkmoths. J. Exp. Biol. 207, 3307-3316. doi: 10.1242/jeb.01158

Blake, A. J., Hahn, G. S., Grey, H., Kwok, S. A., McIntosh, D., and Gries, G. (2020). Polarized light sensitivity in Pieris rapae is dependent on both color and intensity. J. Exp. Biol. 223:jeb220350. doi: 10.1242/jeb.220350

Borges, R. M., Somanathan, H., and Kelber, A. (2016). Patterns and processes in nocturnal and crepuscular pollination services. Q. Rev. Biol. 91, 389-418. doi: $10.1086 / 689481$

Bukovac, Z., Shrestha, M., Garcia, J. E., Burd, M., Dorin, A., and Dyer, A. G. (2017). Why background colour matters to bees and flowers. J. Comp. Physiol. A 203, 369-380. doi: 10.1007/s00359-017-1175-7

Chittka, L., Faruq, S., Skorupski, P., and Werner, A. (2014). Colour constancy in insects. J. Comp. Physiol. A 200, 435-448. doi: 10.1007/s00359-014-0897-z

Chittka, L., Shmida, A., Troje, N., and Menzel, R. (1994). Ultraviolet as a component of flower reflections, and the colour perception of Hymenoptera. Vision Res. 34, 1489-1508. doi: 10.1016/0042-6989(94)90151-1

\section{AUTHOR CONTRIBUTIONS}

Both authors contributed equally to the experiment, wrote this study, and approved the submitted version.

\section{FUNDING}

CJvdK was funded by the Dutch Science Foundation (016.Veni.181.025) and by AFOSR/EOARD (FA9550-19-17005).

\section{ACKNOWLEDGMENTS}

The authors thank Doekele Stavenga and two referees for commenting on an earlier version of this manuscript.

\section{SUPPLEMENTARY MATERIAL}

The Supplementary Material for this article can be found online at: https://www.frontiersin.org/articles/10.3389/fevo.2022. 819436/full\#supplementary-material

Supplementary Figure 1 | The blue and green background spectra used for the model calculations.

Cronin, T. W., Johnsen, S., Marshall, N. J., and Warrant, E. J. (2014). Visual ecology. Princeton: Princeton University Press.

Dyer, A. G., Spaethe, J., and Prack, S. (2008). Comparative psychophysics of bumblebee and honeybee colour discrimination and object detection. J. Comp. Physiol. A 194, 617-627. doi: 10.1007/s00359-0080335-1

Dyer, A. G., Streinzer, M., and Garcia, J. (2016). Flower detection and acuity of the Australian native stingless bee Tetragonula carbonaria Sm. J. Comp. Physiol. A 202, 629-639. doi: 10.1007/s00359-016-1107-y

Ellis, A. G., Anderson, B., and Kemp, J. E. (2021). Geographic mosaics of fly pollinators with divergent color preferences drive landscape-scale structuring of flower color in daisy communities. Front. Plant Sci. 12:617761. doi: 10.3389/ fpls.2021.617761

Finnell, L. M., and Koski, M. H. (2021). A test of Sensory Drive in plant-pollinator interactions: heterogeneity in the signalling environment shapes pollinator preference for a floral visual signal. New Phytol. 232, 1436-1448. doi: 10.1111/ nph.17631

Giurfa, M., and Vorobyev, M. (1998). The angular range of achromatic target detection by honey bees. J. Comp. Physiol. A 183, 101-110. doi: 10.1007/ s003590050238

Giurfa, M., Vorobyev, M., Brandt, R., Posner, B., and Menzel, R. (1997). Discrimination of coloured stimuli by honeybees: alternative use of achromatic and chromatic signals. J. Comp. Physiol. A 180, 235-243. doi: 10.1007/ s003590050044

Giurfa, M., Vorobyev, M., Kevan, P., and Menzel, R. (1996). Detection of coloured stimuli by honeybees: minimum visual angles and receptor specific contrasts. J. Comp. Physiol. A 178, 699-709.

Goyret, J. (2010). Look and touch: multimodal sensory control of flower inspection movements in the nocturnal hawkmoth Manduca sexta. J. Exp. Biol. 213, 3676-3682. doi: 10.1242/jeb.045831

Goyret, J., and Kelber, A. (2012). Chromatic signals control proboscis movements during hovering flight in the hummingbird hawkmoth Macroglossum stellatarum. PLoS One 7:e34629. doi: 10.1371/journal.pone.003 4629 
Goyret, J., Pfaff, M., Raguso, R. A., and Kelber, A. (2008). Why do Manduca sexta feed from white flowers? Innate and learnt colour preferences in a hawkmoth. Naturwissenschaften 95, 569-576. doi: 10.1007/s00114-008-0350-7

Hardie, R. C. (1986). The photoreceptor array of the dipteran retina. Trends Neurosci. 9, 419-423. doi: 10.1016/0166-2236(86)90136-0

Hempel de Ibarra, N., and Giurfa, M. (2003). Discrimination of closed coloured shapes by honeybees requires only contrast to the long wavelength receptor type. Anim. Behav. 66, 903-910. doi: 10.1006/anbe.2003.2269

Hempel de Ibarra, N., Giurfa, M., and Vorobyev, M. (2001). Detection of coloured patterns by honeybees through chromatic and achromatic cues. J. Comp. Physiol. A 187, 215-224. doi: 10.1007/s003590100192

Hempel de Ibarra, N., Vorobyev, M., Brandt, R., and Giurfa, M. (2000). Detection of bright and dim colours by honeybees. J. Exp. Biol. 203, 3289-3298.

Hempel de Ibarra, N., Vorobyev, M., and Menzel, R. (2014). Mechanisms, functions and ecology of colour vision in the honeybee. J. Comp. Physiol. A 200, 411-433. doi: 10.1007/s00359-014-0915-1

Herrera, C. M. (1992). Activity pattern and thermal biology of a dayflying hawkmoth Macroglossum stellatarum under Mediterranean summer conditions. Ecol. Entomol. 17, 52-56. doi: 10.1111/j.1365-2311.1992.tb01038.x

Jezeera, M., Tichit, P., Balamurali, G. S., Baird, E., Kelber, A., and Somanathan, H. (2021). Spatial resolution and sensitivity of the eyes of the stingless bee, Tetragonula iridipennis. J. Comp. Physiol. A. Epub online ahead of print. doi: 10.1007/s00359-021-01521-2

Johnsen, S., Kelber, A., Warrant, E., Sweeney, A. M., Widder, E. A., Lee, R. L., et al. (2006). Crepuscular and nocturnal illumination and its effects on color perception by the nocturnal hawkmoth Deilephila elpenor. J. Exp. Biol. 209, 789-800. doi: 10.1242/jeb.02053

Kelber, A. (2005). Alternative use of chromatic and achromatic cues in a hawkmoth. Proc. R. Soc. London B 272, 2143-2147. doi: 10.1098/rspb.2005.3207

Kelber, A., Balkenius, A., and Warrant, E. J. (2002). Scotopic colour vision in nocturnal hawkmoths. Nature 419, 922-925. doi: 10.1038/nature01065

Kelber, A., and Henze, M. J. (2013). Colour vision: parallel pathways intersect in Drosophila. Curr. Biol. 23, R1043-R1045. doi: 10.1016/j.cub.2013.10.025

Kelber, A., and Osorio, D. (2010). From spectral information to animal colour vision: experiments and concepts. Proc. R. Soc. B 277, 1617-1625. doi: 10.1098/ rspb.2009.2118

Kelber, A., Vorobyev, M., and Osorio, D. (2003). Animal colour visionbehavioural tests and physiological concepts. Biol. Rev. 78, 81-118. doi: 10.1017/ s1464793102005985

Kemp, D. J., Herberstein, M. E., Fleishman, L. J., Endler, J. A., Bennett, A. T. D., Dyer, A. G., et al. (2015). An integrative framework for the appraisal of coloration in nature. Am. Nat. 185, 705-724. doi: 10.1086/681021

Kevan, P., Giurfa, M., and Chittka, L. (1996). Why are there so many and so few white flowers? Trends Plant Sci. 1, 252-527. doi: 10.1016/1360-1385(96) 20008-1

Kevan, P. G., and Baker, H. G. (1983). Insects as flower visitors and pollinators. Annu. Rev. Entomol. 28, 407-453.

Kinoshita, M., Takahashi, Y., and Arikawa, K. (2012). Simultaneous brightness contrast of foraging Papilio butterflies. Proc. R. Soc. London B Biol. Sci. 279, 1911-1918. doi: 10.1098/rspb.2011.2396

Kinoshita, M., Yamazato, K., and Arikawa, K. (2011). Polarization-based brightness discrimination in the foraging butterfly, Papilio xuthus. Philos. Trans. R. Soc. B Biol. Sci. 366, 688-696. doi: 10.1098/rstb.2010.0200

Koethe, S., Bossems, J., Dyer, A. G., and Lunau, K. (2016). Colour is more than hue: preferences for compiled colour traits in the stingless bees Melipona mondury and M. quadrifasciata. J. Comp. Physiol. A 202, 615-627. doi: 10.1007/s00359016-1115-y

Koshitaka, H., Arikawa, K., and Kinoshita, M. (2011). Intensity contrast as a crucial cue for butterfly landing. J. Comp. Physiol. A 197, 1105-1112. doi: 10.1007/ s00359-011-0671-4

Kuenzinger, W., Kelber, A., Weesner, J., Travis, J., Raguso, R. A., and Goyret, J. (2019). Innate colour preferences of a hawkmoth depend on visual context. Biol. Lett. 15:20180886. doi: 10.1098/rsbl.2018.0886

Lehrer, M., and Bischof, S. (1995). Detection of model flowers by honeybees: the role of chromatic and achromatic contrast. Naturwissenschaften 82, 145-147.

Lehrer, M., Srinivasan, M. V., and Zhang, S. W. (1990). Visual edge detection in the honeybee and its chromatic properties. Proc. R. Soc. B 238, 321-330. doi: $10.1098 / \mathrm{rspb} .1990 .0002$
Lunau, K., and Maier, E. J. (1995). Innate colour preferences of flower visitors. J. Comp. Physiol. A 177, 1-19.

Martínez-Harms, J., Vorobyev, M., Schorn, J., Shmida, A., Keasar, T., Homberg, U., et al. (2012). Evidence of red sensitive photoreceptors in Pygopleurus israelitus (Glaphyridae: Coleoptera) and its implications for beetle pollination in the southeast Mediterranean. J. Comp. Phys. A 198, 451-463. doi: 10.1007/s00359012-0722-5

Meena, A., Kumar, A. M. V., Balamurali, G. S., and Somanathan, H. (2021). Visual detection thresholds in the Asian honeybee, Apis cerana. J. Comp. Physiol. A 207, 553-560. doi: 10.1007/s00359-021-01496-0

Menzel, R. (1981). Achromatic vision in the honeybee at low light intensities. J. Comp. Phys. A 141, 389-393. doi: 10.1007/bf00609941

Menzel, R., Gumbert, A., Kunze, J., Shmida, A., and Vorobyev, M. (1997). Pollinators' strategies in finding flowers. Isr. J. Plant Sci. 45, 141-156.

Menzel, R., and Shmida, A. (1993). The ecology of flower colours and the natural colour vision of insect pollinators: the Israeli flora as a study case. Biol. Rev. 68, $81-120$.

Narbona, E., Del Valle, J. C., Arista, M., Buide, M. L., and Ortiz, P. L. (2021). Major flower pigments originate different colour signals to pollinators. Front. Ecol. Evol. 9:743850. doi: 10.3389/fevo.2021.743850

Ng, L., Garcia, J. E., and Dyer, A. G. (2018). Why colour is complex: evidence that bees perceive neither brightness nor green contrast in colour signal processing. Facets 3, 800-817.

Niggebrügge, C., and Hempel de Ibarra, N. (2003). Colour-dependent target detection by bees. J. Comp. Physiol. A 189, 915-918. doi: 10.1007/s00359-0030466-3

Nilsson, D.-E. (2021). The diversity of eyes and vision. Annu. Rev. Vis. Sci. 7, 19-41. doi: 10.1146/annurev-vision-121820-074736

Osorio, D., and Vorobyev, M. (2005). Photoreceptor sectral sensitivities in terrestrial animals: adaptations for luminance and colour vision. Proc. R. Soc. London B Biol. Sci. 272, 1745-1752. doi: 10.1098/rspb.2005.3156

Pagni, M., Haikala, V., Oberhauser, V., Meyer, P. B., Reiff, D. F., and Schnaitmann, C. (2021). Interaction of "chromatic" and "achromatic" circuits in Drosophila color opponent processing. Curr. Biol. 31, 1687-1698.e4. doi: 10.1016/j.cub. 2021.01.105

Peitsch, D., Fietz, A., Hertel, H., Desouza, J., Ventura, D. F., and Menzel, R. (1992). The spectral input systems of hymenopteran insects and their receptorbased color-vision. J. Comp. Physiol. A 170, 23-40. doi: 10.1007/BF0019 0398

Prokopy, R. J., Economopoulos, A. P., and McFadden, M. W. (1975). Attraction of wild and laboratory-cultured Dacus oleae flies to small rectangles of different hues, shades, and tints. Entomol. Exp. Appl. 18, 141-152. doi: 10.1111/j.15707458.1975.tb02364.x

Reisenman, C. E., and Giurfa, M. (2008). Chromatic and achromatic stimulus discrimination of long wavelength (red) visual stimuli by the honeybee Apis mellifera. Arthropod. Plant. Interact. 2, 137-146.

Rusanen, J., Frolov, R., Weckström, M., Kinoshita, M., and Arikawa, K. (2018). Non-linear amplification of graded voltage signals in the first-order visual interneurons of the butterfly Papilio xuthus. J. Exp. Biol. 221:jeb179085. doi: 10.1242/jeb.179085

Satoh, A., Kinoshita, M., and Arikawa, K. (2016). Innate preference and learning of colour in the male cotton bollworm moth, Helicoverpa armigera. J. Exp. Biol. 219, 3857-3860. doi: 10.1242/jeb.148064

Schnaitmann, C., Garbers, C., Wachtler, T., and Tanimoto, H. (2013). Color discrimination with broadband photoreceptors. Curr. Biol. 23, 2375-2382. doi: 10.1016/j.cub.2013.10.037

Somanathan, H., Borges, R. M., Warrant, E. J., and Kelber, A. (2008). Nocturnal bees learn landmark colours in starlight. Curr. Biol. 18, R996-R997. doi: 10. 1016/j.cub.2008.08.023

Spaethe, J., Streinzer, M., Eckert, J., May, S., and Dyer, A. G. (2014). Behavioural evidence of colour vision in free flying stingless bees. J. Comp. Physiol. A 200, 485-496. doi: 10.1007/s00359-014-0886-2

Spaethe, J., Tautz, J., and Chittka, L. (2001). Visual constraints in foraging bumblebees: flower size and color affect search time and flight behavior. Proc. Natl. Acad. Sci. 98, 3898-3903. doi: 10.1073/pnas.071053098

Sprengel, C. K. (1793). Das Entdeckte Geheimniss der Natur im Bau und in der Befruchtung der Blumen. Germany: Friedrich Vieweg. 
Srinivasan, M. V. (1985). Shouldn't directional movement detection necessarily be "colour-blind"? Vision Res. 25, 997-1000. doi: 10.1016/0042-6989(85)90210-x

Srinivasan, M. V., and Lehrer, M. (1988). Spatial acuity of honeybee vision and its spectral properties. J. Comp. Physiol. A 162, 159-172. doi: 10.1007/bf00606081

Stavenga, D. G., Staal, M., and van der Kooi, C. J. (2020). Conical epidermal cells cause velvety colouration and enhanced patterning in: Mandevilla flowers. Faraday Discuss. 223, 98-106. doi: 10.1039/d0fd00055h

Stavenga, D. G., and van der Kooi, C. J. (2016). Coloration of the Chilean Bellflower, Nolana paradoxa, interpreted with a scattering and absorbing layer stack model. Planta 243, 171-181. doi: 10.1007/s00425-015-2395-0

Stewart, F. J., Kinoshita, M., and Arikawa, K. (2015). The butterfly Papilio xuthus detects visual motion using chromatic contrast. Biol. Lett. 11:20150687. doi: $10.1098 / \mathrm{rsbl} .2015 .0687$

Stöckl, A. L., and Kelber, A. (2019). Fuelling on the wing: sensory ecology of hawkmoth foraging. J. Comp. Physiol. A 205, 399-413. doi: 10.1007/s00359019-01328-2

Streinzer, M., Paulus, H. F., and Spaethe, J. (2009). Floral colour signal increases short-range detectability of a sexually deceptive orchid to its bee pollinator. J. Exp. Biol. 212, 1365-1370. doi: 10.1242/jeb.027482

Telles, F. J., Lind, O., Henze, M. J., Rodríguez-Gironés, M. A., Goyret, J., and Kelber, A. (2014). Out of the blue: the spectral sensitivity of hummingbird hawkmoths. J. Comp. Physiol. A 200, 537-546. doi: 10.1007/s00359-014-0888-0

Tinbergen, J., and Abeln, R. G. (1983). Spectral sensitivity of the landing blowfly. J. Comp. Physiol. A 150, 319-328. doi: 10.1007/bf00605021

Turner, C. H. (1910). Experiments on color-vision of the honey bee. Biol. Bull. 19, 257-279. doi: 10.2307/1536088

Ushimaru, A., Rin, I., and Katsuhara, K. R. (2021). Covering and shading by neighbouring plants diminish pollinator visits to and reproductive success of a forest edge specialist dwarf species. Plant Biol. 23, 711-718. doi: 10.1111/plb. 13267

Van Breugel, F., and Dickinson, M. H. (2012). The visual control of landing and obstacle avoidance in the fruit fly Drosophila melanogaster. J. Exp. Biol. 215 1783-1798. doi: 10.1242/jeb.066498

van der Kooi, C. J. (2021). How much pigment should flowers have? Flowers with moderate pigmentation have highest colour contrast. Front. Ecol. Evol. 9:731626. doi: $10.3389 /$ fevo.2021.731626

van der Kooi, C. J., Dyer, A. G., Kevan, P. G., and Lunau, K. (2019). Functional significance of the optical properties of flowers for visual signalling. Ann. Bot. 123, 263-276. doi: 10.1093/aob/mcy119

van der Kooi, C. J., Elzenga, J. T. M., Dijksterhuis, J., and Stavenga, D. G. (2017). Functional optics of glossy buttercup flowers. J. R. Soc. Interface 17:20160933. doi: 10.1098/rsif.2016.0933 van der Kooi, C. J., Elzenga, J. T. M., Staal, M., and Stavenga, D. G. (2016). How to colour a flower: on the optical principles of flower coloration. Proc. R. Soc. B 283:20160429. doi: 10.1098/rspb.2016.0429

van der Kooi, C. J., and Stavenga, D. G. (2019). Vividly coloured poppy flowers due to dense pigmentation and strong scattering in thin petals. J. Comp. Physiol. A 205, 363-372. doi: 10.1007/s00359-018-01313-1

van der Kooi, C. J., Stavenga, D. G., Belusic, G., Arikawa, K., and Kelber, A. (2021). Evolution of insect color vision: from spectral sensitivity to visual ecology. Annu. Rev. Entomol. 66, 435-462. doi: 10.1146/annurev-ento-061720-071644

Vasas, V., Hanley, D., Kevan, P. G., and Chittka, L. (2017). Multispectral images of flowers reveal the adaptive significance of using long-wavelength-sensitive receptors for edge detection in bees. J. Comp. Physiol. A 203, 301-311. doi: 10.1007/s00359-017-1156-x

von Frisch, K. (1914). Der Farbensinn und Formensinn der Biene. Zool. Jahrbücher. Abteilung für Allg. Zool. und Physiol. der Tiere 35, 1-188.

Wardill, T. J., List, O., Li, X., Dongre, S., McCulloch, M., Ting, C.-Y., et al. (2012). Multiple spectral inputs improve motion discrimination in the Drosophila visual system. Science 336, 925-931. doi: 10.1126/science.1215317

Werner, A., Menzel, R., and Wehrhahn, C. (1988). Color constancy in the honeybee. J. Neurosci. 8, 156-159. doi: 10.1523/JNEUROSCI.08-01-00156.1988

Wertlen, A. M., Niggebrügge, C., Vorobyev, M., and de Ibarra, N. H. (2008). Detection of patches of coloured discs by bees. J. Exp. Biol. 211, 2101-2104. doi: $10.1242 /$ jeb.014571

Yang, X., Li, M., Fan, F., An, L., Li, J., and Wei, G. (2020). Brightness mediates oviposition in crepuscular moth, Grapholita molesta. J. Pest Sci. 93, 1311-1319.

Conflict of Interest: The authors declare that the research was conducted in the absence of any commercial or financial relationships that could be construed as a potential conflict of interest.

Publisher's Note: All claims expressed in this article are solely those of the authors and do not necessarily represent those of their affiliated organizations, or those of the publisher, the editors and the reviewers. Any product that may be evaluated in this article, or claim that may be made by its manufacturer, is not guaranteed or endorsed by the publisher.

Copyright $\odot 2022$ van der Kooi and Kelber. This is an open-access article distributed under the terms of the Creative Commons Attribution License (CC BY). The use distribution or reproduction in other forums is permitted, provided the original author(s) and the copyright owner(s) are credited and that the original publication in this journal is cited, in accordance with accepted academic practice. No use, distribution or reproduction is permitted which does not comply with these terms. 